\title{
Physico-Chemical Evaluation of Groundwater in Kuje, Federal Capital Territory, Abuja, Nigeria
}

\author{
K. O. Ibrahim ${ }^{1 *}$, O. Joel ${ }^{2}$, A. Abdulrahman ${ }^{1}$, S. A. Bankole ${ }^{3}$ \\ ${ }^{1}$ Department of Geology and Mineral Sciences, University of Ilorin, P.M.B. 1515, Ilorin, Nigeria. \\ ${ }^{2}$ Department of Geology, Federal University of Technology, P.M.B. 65, Minna, Nigeria. \\ ${ }^{3}$ Department of Chemical and Geological Sciences, Al-Hikmah University, P.M.B.1601, Ilorin, Nigeria.
}

\begin{abstract}
This study was done to determine the quality of water from hand-dug wells in Kuje, Federal Capital Territory Abuja Nigeria. The study area lies between latitudes $08^{\circ} 53^{\prime} 24^{\prime \prime} \mathrm{N}$ and $08^{\circ} 53^{\prime} 47^{\prime} \mathrm{N}$ and longitude $07^{\circ} 14^{\prime} 24^{\prime \prime} \mathrm{E}$ and $07^{\circ} 14^{\prime}$ $35^{\prime}$ 'E. Water from twenty wells were randomly sampled. The physical properties investigated are $\mathrm{pH}$, temperature, total dissolved solid (TDS) and electrical conductivity. The chemical analysis involved determination of the concentration of anions $\left(\mathrm{SO}_{4}{ }^{2-}, \mathrm{HCO}_{3}^{-}, \mathrm{Fl}^{-}, \mathrm{CO}_{3}^{-}, \mathrm{Cl}^{-}, \mathrm{NO}_{3}\right)$ and cations $\left(\mathrm{Ca}^{2+}, \mathrm{Mg}^{+}, \mathrm{Na}^{+}, \mathrm{K}^{+}, \mathrm{Zn}^{+}, \mathrm{Fe}^{2+}, \mathrm{Cu}^{2+}\right.$. A piper diagram based on the relative percentages of the ions was plotted for classification according to hydrogeochemical facies of each water sample based on their dominant ions. The Piper diagram indicated $\mathrm{Ca}^{2+}$ and $\mathrm{HCO}_{3}{ }^{-}$as the dominant ions and therefore it is $\mathrm{Ca}-\mathrm{HCO}_{3}$ water type. The physical properties of the water were found to be good based on World Health Organization (WHO) guidelines and National Drinking Water Quality Standard (NDWQS) and therefore water in the study area is safe for human consumption.
\end{abstract}

KEYWORDS: groundwater, hydrochemical facies, anion, cation, piper diagram

[Received October 22 2013; Revised April 162014 \& January 25 2015; Accepted June 6 2015]

\section{INTRODUCTION}

Increase in demand for water resources globally occurs essentially due to population growth and modern developments. Thus the welfare of every society is tied to the sustainable exploitation of water resources (Bear, 2000). Groundwater accounts for about 98\% of the world's fresh water and it is fairly well distributed throughout the world (Buchanan, 1983). Groundwater continues to serve as a reliable source of water supply in most rural and urban communities in Nigeria. Groundwater is a renewable resource, its availability and use of which are influenced by many factors such as the lithology of the area, climatic patterns and water quality (Anornu et al., 2009). However, human activities and seepage of hazardous materials into groundwater have affected its quality (Olasehinde, 1998; Ajibade et al., 1987). In Nigeria groundwater is an important resource both in the rural and urban areas and is susceptible to quality degradation from anthropogenic activities.

The attendant increase in water pollution and implication to the environment has been studied by several researchers. The studies have highlighted the need for thorough assessment of the quality of water used for human consumption, agricultural and industrial purposes.

Amadi, Olasehinde, and Okosun (2010) used Water Quality Index (WQI) method to evaluate the quality of Otamiri and Oramiriukwa Rivers in Owerri, Nigeria. About 180 samples of water were collected for physicochemical and bacteriological analysis using APHA standard methods of analysis. The overall WQI for all the samples was said to be 174.49. Eludoyin, Ofoezie and Ogunkoya (2004) determined the effect of Oja-titun market effluent on the chemical quality of receiving Opa Reservoir in Ile-Ife, Nigeria. Water samples were collected in sixteen sites, four along each of the market drainage channels, market stream, tributary system and the Opa River and reservoir. Ige, Bale and Olasehinde (2008) evaluated the physio-chemical characteristic of water sources in Imeko, South-western, Nigeria.

The peak level of each variable-biochemical oxygen demand, temperature, total alkalinity, $\mathrm{Na}+\mathrm{K}+\mathrm{Ca}^{2+} \mathrm{Mg}^{2+}$, $\mathrm{P}^{2-}, \mathrm{SO}_{4}^{+}, \mathrm{Cl}^{\prime} \mathrm{NO}^{-3}, \mathrm{~Pb}$ and $\mathrm{Zn}$ that occurred at the areas decreased significantly downstream, except $\mathrm{pH}$, conductivity, total dissolved oxygen which increased. There were high values in the early day and dry season and low values in the rainy and early rainy season. Comparison of the reservoir water with international standard for drinking water supply showed that the quality of the reservoir water was very low.

A total of twenty two (22) water samples within and around Imeko town were collected for analysis. The water samples comprise of eighteen (18) hand dug wells, two (2) boreholes and two (2) spring sources. The hydrochemical characteristics of the area revealed that the cationic concentrations is in the order of $\mathrm{Mg}>\mathrm{Ca}>(\mathrm{Na}+)$ for the wells, boreholes and surface water sources while the anionic concentration is in the order of $\mathrm{HCo} 3>\mathrm{SO} 4>\mathrm{Cl}$. Statistical and graphical approaches of interpretation indicated two different types of water present in the study area which are $\mathrm{Mg}, \mathrm{Ca}^{-}, \mathrm{K}^{+}, \mathrm{Na}^{-} \mathrm{HCO} 3$ and the $\mathrm{Ca}-$ $\mathrm{K}+\mathrm{NaSO} 4$. The $\mathrm{Mg}-\mathrm{HCO} 3$ type shows the predominant marine sources of pollution while the $\mathrm{Ca}-\mathrm{So} 4$ type water is from industrial sources.

Usman and Dosumu (2006) analysed cadmium in fertilizers and ground water samples in Dass Local Government Area of Bauchi State, Nigeria. Five different market samples of 
fertilizers used by farmers in Bauchi State were purchased and analysed for their cadmium (Cd) content using Atomic Absorption Spectrophotometer (AAS). The groundwater was collected from different sites where rice is under intensive cultivation and heavy fertilizer application for between 5 to 30 years period. Long term application of fertilizers on rice farm was found to be responsible for high concentration of $\mathrm{Cd}$ in the groundwater. The studies have highlighted the need for thorough assessment of the quality of water used for human consumption, agricultural and industrial purposes.

Berhanu (1996) described the origin of high bicarbonate and fluoride concentrations in water of the main Ethiopian Rift Valley, East African Rift and from deep wells reaching depths of up to $2500 \mathrm{~m}$ below the surface in the AlutoLangano Geothermal field. The thermal water in the Main Ethiopian Rift Valley are characterized by high $\mathrm{Na}$, bicarbonate and fluoride concentrations and near-neutral to alkaline $\mathrm{pH}$ while sodium, bicarbonate and fluoride are positively correlated in the water. The principal reason for the bicarbonate in the area is the high rate of carbondioxide out gassing. This combined with acid volcanics, geothermal heating, low $\mathrm{Ca}$ and low salinity is also one of the causes of high fluoride in this part of the active volcanic zone of the East African rift. Evaporative concentration is responsible for the high salinity, alkalinity and fluoride in the closed-basin lakes of the region.

The purpose of this research was to undertake a physicochemical analysis of water from twenty hand-dug shallow wells in Kuje area of the Federal Capital Territory (FCT), Abuja, Nigeria and to compare the quality with the water quality standard of the World Health Organization (WHO).

\section{GEOLOGICAL SETTINGS}

The study area, Kuje, is in the south-eastern part of Federal Capital Territory, Abuja. It lies between latitudes 080 53' 24', $\mathrm{N}$ and 080 53' 47' $\mathrm{N}$ and longitudes 070 14' 24' $\mathrm{E}$ and 070 14 ' 35', E. It is located at about $13.2 \mathrm{~km}$ from Abuja municipality. The study area is predominantly underlain by the Precambrian basement complex rocks. The basement complex of Nigeria has been classified in several ways. But the most recent and widely accepted is the classification of Oyawoye (1964) which is basically classified into three main geological units namely; migmatite-gneiss complex, older granite suite sometimes called the intrusive suite and the schist belt.

The polycyclic migmatite gneiss complex consist of high grade rocks mainly migmatite and gneiss of largely uncertain origin with relics of amphibolites. The gneiss migmatite complex is believed to have been initially established in the Archean time and affected by several orogenic events of which the most important is the Liberian event which is 2,750 \pm 50 myrs. The older granite suites consist of granite, granodiorite which truncates or crosscut both the gneiss migmatite complex and the schist belts. They range from granitoid to underformed granite.

The subordinate member includes pegmatite vein, quartz and aplite. The rocks found in the older granite suites are all of pan African age that is $600 \pm 10$ myrs. The schist belt consists mainly of pelitic and semi politic metasediments interbedded with metamorphosed mafic to ultramafic volcanics. They occur as a relatively narrow North-South trending belt within the gneiss migmatite complex, and are believed to be vestiges of supracrustal sediments which were folded into pre-existing bedrock known to be at least of paleoproterozic age. Examples of the schist belts include: Jebba quartz, Efon granite formation, the metamorphic grade of the rocks ranges from medium to low grade.

However, the local lithological units in the study area are migmatite gneiss, granite, and schistose gneiss. The migmatite gneiss is the most wide spread rock unit, while the granite occurs in several locations. They are porphyritic and of medium-coarse-grained texture. Granites mostly occur as intrusive, low-lying outcrops around the gneiss. They are severely jointed and fairly intruded by quartz veins (Oyawoye, 1964). The area is drained by seasonal streams. The topography is characterized by flat and elevated terrains. Plate 1 shows the granite of the study area while migmatite-gneiss is shown in Plate 2.

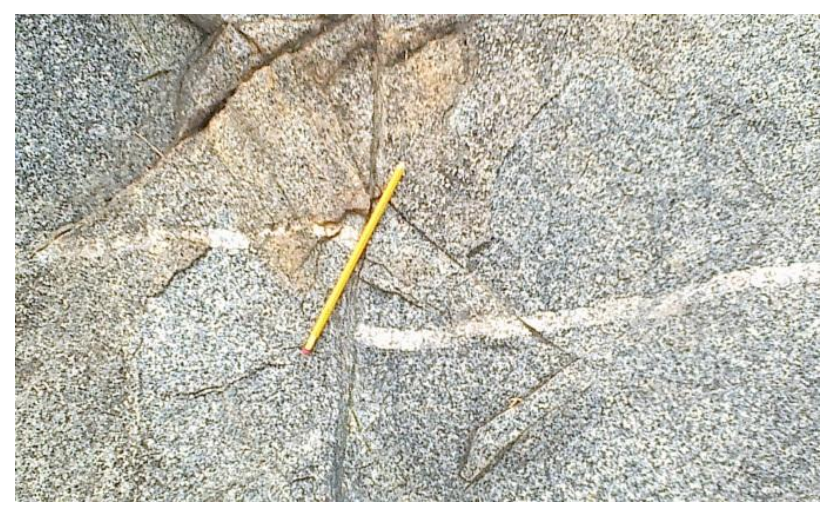

Plate 1: Granite with joints in the study area.

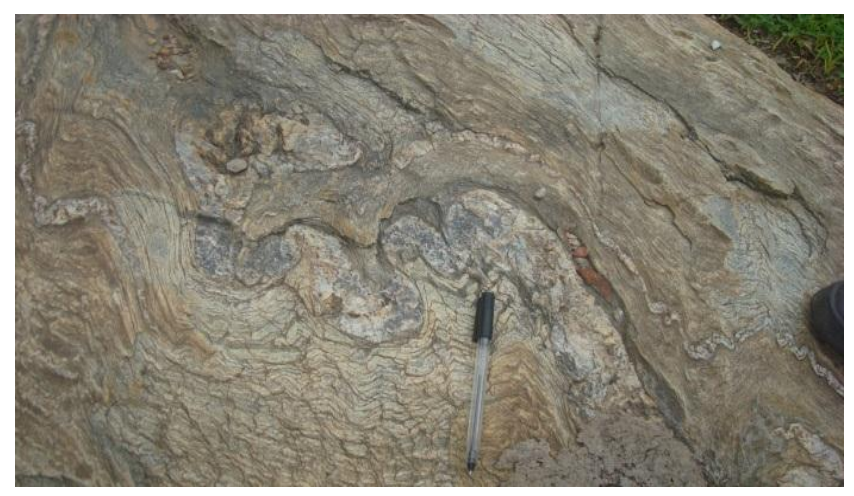

Plate 2: Migmatite gnesis in the study area.

\section{MATERIALS AND METHODS}

Samples of well water at the study area shown in Figure 1 were collected and properly labelled at the location of collection. Twenty groundwater samples were collected. The 


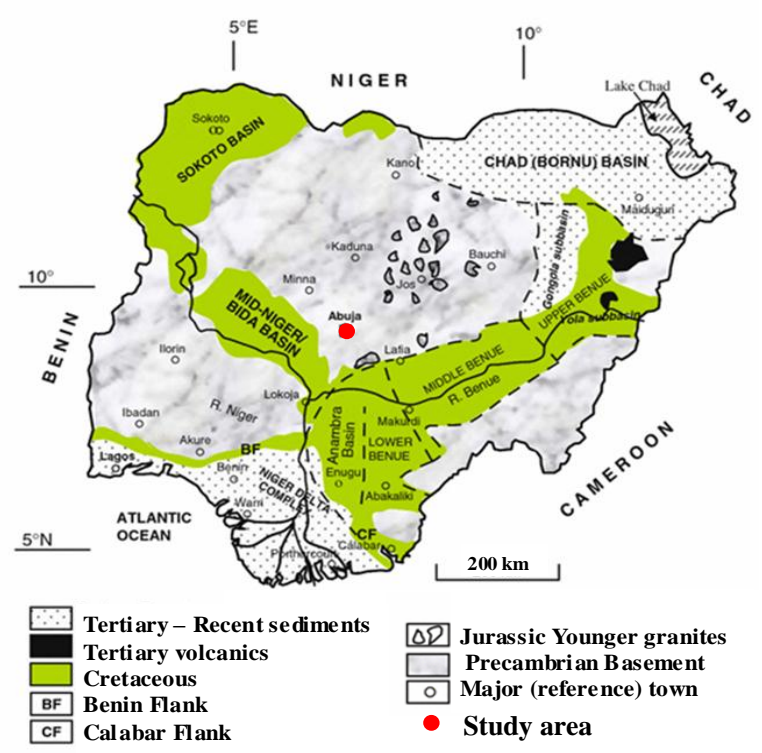

Figure 1: Geological map of Nigeria showing the study area.

water samples were collected using 2 litre containers which were initially washed with detergents and samples were immediately covered with a scale cap to avoid reaction with atmospheric oxygen.

The static water level in the wells and the total depth of wells were measured with a weighted graduated tape. The elevation, longitude and latitude of the well location were observed using Global Positioning System (GPS). The water temperature, $\mathrm{pH}$, total dissolved solid (TDS), conductivity and salinity were measured in-situ using $\mathrm{pH}$ meter, thermometer and salinity meter. The samples were analysed in the laboratory within 48 hours of collection using an atomic absorption spectrophotometry (AAS) whose schematic diagram is shown in Figure 2. The cations analysed are $\mathrm{Ca}^{+}$, $\mathrm{Mg}^{+}, \mathrm{Na}^{+}, \mathrm{K}^{+}, \mathrm{Cu}^{2+}, \mathrm{Fe}^{2+}, \mathrm{Zn}^{2+}$, and the anions are $\mathrm{NO}_{3}, \mathrm{SO}_{4}^{2-}$, $\mathrm{Cl}^{-}, \mathrm{HCO}_{3}^{-}, \mathrm{Fl}^{-}, \mathrm{CO}_{3}^{-}$.

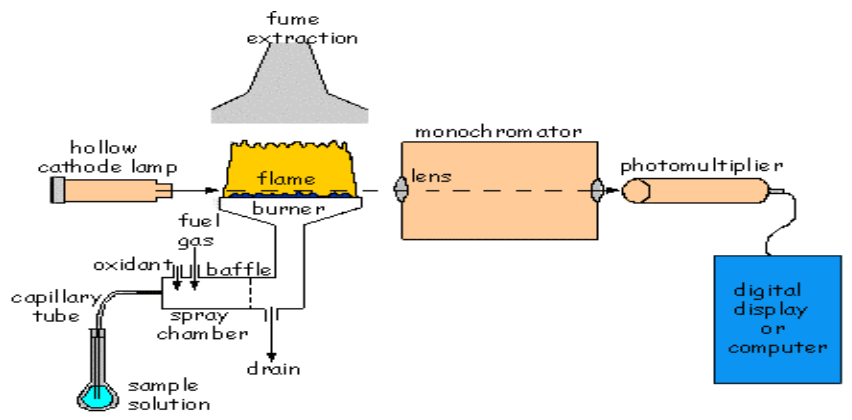

Source: http://www.thebritishmuseum.ac.uk/science/techniques/sr-techaas.

Figure 2: Schematic diagram of atomic absorption spectrophotometry.

\section{RESULTS AND DISCUSSION}

The $\mathrm{pH}$ of water samples ranged from 6.47 to 6.94 , as presented in Table 1. These values fall within the acceptable Nigerian standards (2007) and World Health Organization standards (1996) for potable water. The total dissolved solids (TDS) of the water ranged from $420 \mathrm{mg} / \mathrm{l}$ to $1258 \mathrm{mg} / \mathrm{l}$, indicating a high concentration of total dissolved solids when compared with World Health Organization Standards (1996).The electrical conductivity ranged from $686 \mu \mathrm{S} / \mathrm{cm}$ to $1935 \mu \mathrm{S} / \mathrm{cm}$ and may have been affected by the high TDS as shown in Table1. The temperature of the groundwater ranged from $27.5^{\circ} \mathrm{C}$ to $29.9^{\circ} \mathrm{C}$.

Table 1: Results of Physical Parameters.

\begin{tabular}{|c|c|c|c|c|c|c|c|}
\hline Loc. & $\begin{array}{l}\text { Long. } \\
\text { (N) }\end{array}$ & Lat. (E) & pH & $\begin{array}{c}\text { Cond } \\
(\mu \mathrm{S} / \mathrm{cm})\end{array}$ & $\begin{array}{c}\text { TDS } \\
\text { (mg/l) }\end{array}$ & $\begin{array}{c}\text { Temp } \\
\left({ }^{\circ} \mathrm{C}\right)\end{array}$ & Sal. \\
\hline 1. & $08^{0} 52^{\prime} 7^{\prime \prime}$ & $07^{0} 13^{\prime} 7^{\prime \prime}$ & 6.4 & 1935 & 1258 & 27.5 & 1.5 \\
\hline 2. & $08^{0} 52^{\prime} 7^{\prime \prime}$ & $07^{0} 13^{\prime} 7^{\prime \prime}$ & 6.4 & 892 & 580 & 27.5 & 1.5 \\
\hline 3. & $08^{0} 52^{\prime} 6^{\prime \prime}$ & $07^{0} 13^{\prime} 6^{\prime \prime}$ & 6.6 & 1025 & 669 & 28.8 & 2.2 \\
\hline 4. & $08^{0} 52^{\prime} 6^{\prime \prime}$ & $07^{0} 13^{\prime} 7^{\prime \prime}$ & 6.6 & 714 & 470 & 28.9 & 2.1 \\
\hline 5. & $08^{0} 52^{\prime} 6^{\prime \prime}$ & $07^{0} 13^{\prime} 7^{\prime \prime}$ & 6.5 & 1241 & 761 & 28.7 & 2.2 \\
\hline 6. & $08^{0} 52^{\prime} 6^{\prime \prime}$ & $07^{0} 13^{\prime} 6^{\prime \prime}$ & 6.5 & 998 & 561 & 28.7 & 2.1 \\
\hline 7. & $08^{0} 52^{\prime} 61$ & $07^{0} 13^{\prime} 6^{\prime \prime}$ & 6.5 & 686 & 420 & 28.6 & 2.9 \\
\hline 8. & $08^{0} 52^{\prime} 6^{\prime \prime}$ & $07^{0} 13^{\prime} 6^{\prime \prime}$ & 6.9 & 1271 & 835 & 29.0 & 1.9 \\
\hline 9. & $08^{0} 52^{\prime} 7^{\prime \prime}$ & $07^{0} 13^{\prime} 6^{\prime \prime}$ & 6.9 & 1761 & 1144 & 29.4 & 2.2 \\
\hline 10. & $08^{0} 52^{\prime} 7^{\prime}$ & $07^{0} 13^{\prime} 6^{\prime \prime}$ & 6.9 & 1556 & 1013 & 29.7 & 2.1 \\
\hline 11. & $08^{0} 52^{\prime} 7^{\prime}$ & $07^{0} 13^{\prime} 7^{\prime \prime}$ & 6.9 & 987 & 650 & 29.4 & 1.6 \\
\hline 12. & $08^{0} 52^{\prime} 7^{\prime \prime}$ & $07^{0} 13^{\prime} 6^{\prime \prime}$ & 6.9 & 1183 & 770 & 28.6 & 1.7 \\
\hline 13. & $08^{0} 52^{\prime} 8^{\prime \prime}$ & $07^{0} 13^{\prime} 9^{\prime \prime}$ & 6.9 & 1599 & 1043 & 29.5 & 1.3 \\
\hline 14. & $08^{0} 52^{\prime} 8^{\prime \prime}$ & $07^{0} 13^{\prime} 9$ '” & 6.9 & 946 & 620 & 28.8 & 2.1 \\
\hline 15. & $08^{0} 52^{\prime} 7^{\prime \prime}$ & $07^{0} 13^{\prime} 9^{\prime \prime}$ & 6.8 & 883 & 581 & 28.8 & 1.5 \\
\hline 16. & $08^{0} 52^{\prime} 7^{\prime}$ & $07^{0} 13^{\prime} 9{ }^{\prime \prime}$ & 6.9 & 1429 & 930 & 28.3 & 1.6 \\
\hline 17. & $08^{0} 52^{\prime} 8^{\prime \prime}$ & $07^{0} 13^{\prime} 10^{\prime \prime}$ & 6.9 & 1305 & 860 & 28.6 & 1.8 \\
\hline 18. & $08^{0} 52^{\prime} 7^{\prime \prime}$ & $07^{0} 14^{\prime} 01^{\prime \prime}$ & 6.9 & 1088 & 710 & 29.4 & 2.5 \\
\hline 19. & $08^{0} 52^{\prime} 7^{\prime}$ & $07^{0} 14^{\prime} 00^{\prime \prime}$ & 6.9 & 794 & 480 & 29.2 & 1.8 \\
\hline 20. & $08^{0} 52^{\prime} 7^{\prime \prime}$ & $07^{0} 14^{\prime} 03^{\prime \prime}$ & 6.9 & 1466 & 965 & 29.9 & 1.3 \\
\hline
\end{tabular}

On the basis of physical properties, groundwater in Kuje area is fit for human consumption. The high TDS can be reduced using simple filters. The concentrations of $\mathrm{Mg}^{2+}, \mathrm{Na}^{+}$, $\mathrm{Cu}^{2+}, \mathrm{Ca}^{2+}, \mathrm{Zn}^{2+}, \mathrm{Fe}^{2+}, \mathrm{NO}_{3}^{-}, \mathrm{SO}_{4}^{2-}$, and $\mathrm{Cl}^{-}$are within the permissible limits of the WHO (1996) standards for potable water as shown in Table 2. The piper plot for the chemical constituents of the water reveals $\mathrm{Ca}^{2+}$ and $\mathrm{HCO}_{3}^{-}$as the dominant ions and therefore it is $\mathrm{Ca}-\mathrm{HCO} 3$ water type as shown in Figure 3.

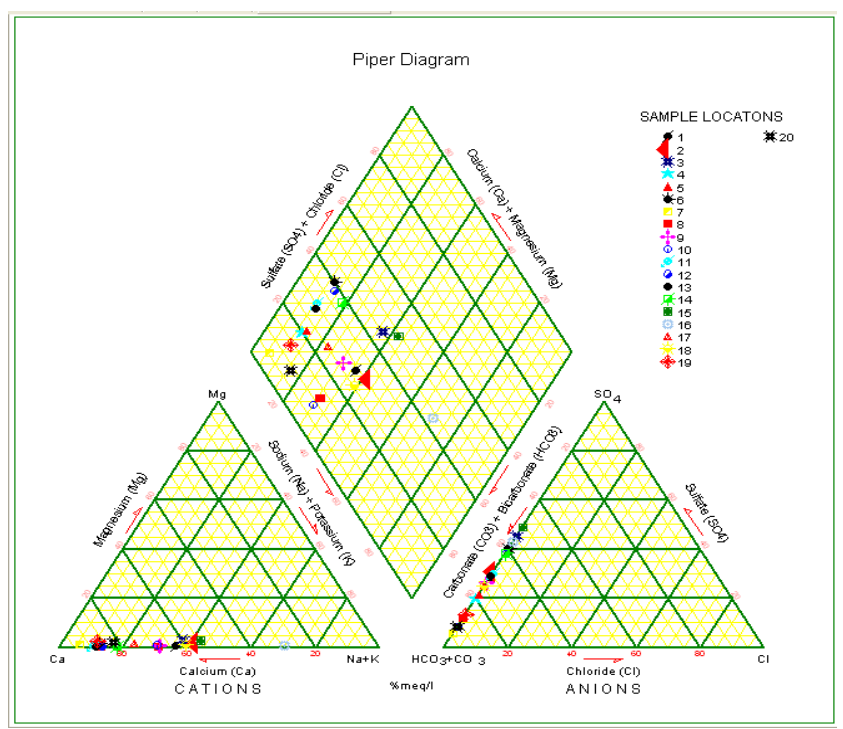

Figure 3: Piper diagram of groundwater in Kuje. 
Table 2: Concentration of major cations and anions in milligram per litre (mg/l) of the study area.

\begin{tabular}{|c|c|c|c|c|c|c|c|c|c|c|c|c|c|c|c|}
\hline لٍْ & 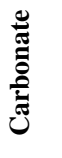 & 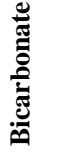 & 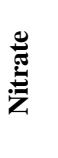 & 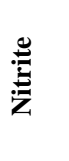 & 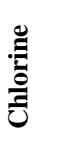 & 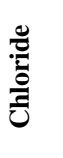 & 声 & 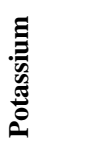 & 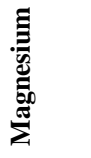 & 罵 & & 声 & 芯 & 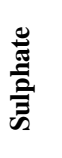 & 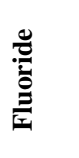 \\
\hline 1 & 65 & 105 & 52 & 30 & 0.41 & 28 & 10 & 28 & 0.3 & 0.14 & 0.4 & 40 & 0.06 & 75 & 1.57 \\
\hline 2 & 28 & 56 & 37 & 15 & 0.34 & 15 & 25 & 9.5 & 0.71 & 0.75 & 0.21 & 35 & 0.08 & 40 & 1.9 \\
\hline 3 & 18 & 48 & 63 & 41 & 0.23 & 32 & 8 & 19.3 & 0.84 & 0.38 & 0.11 & 27 & 0.03 & 55 & 1.58 \\
\hline 4 & 60 & 110 & 46 & 25 & 0.11 & 7 & 4 & 8.2 & 0.51 & 0.24 & 0.25 & 56 & 0.01 & 45 & 0.11 \\
\hline 5 & 70 & 120 & 38 & 9 & 0.45 & 21 & 18 & 5.13 & 0.22 & 0.06 & 0.08 & 120 & 0.01 & 57 & 0.15 \\
\hline 6 & 15 & 45 & 41 & 15 & 0.14 & 25 & 6 & 3.65 & 0.61 & 0.16 & 0.09 & 52 & 0.05 & 40 & 0.14 \\
\hline 7 & 18 & 68 & 34 & 12 & 0.06 & 13 & 1.5 & 3.18 & 0.4 & 0.03 & 0.29 & 45 & 0.11 & 5 & 3.69 \\
\hline 8 & 64 & 104 & 54 & 20 & 0.38 & 8 & 22 & 24 & 0.21 & 0.06 & 0.23 & 70 & 0.2 & 25 & 4.31 \\
\hline 9 & 45 & 85 & 37 & 23 & 0.3 & 24 & 23 & 18 & 0.48 & 0.08 & 0.12 & 64 & 0.04 & 50 & 1.5 \\
\hline 10 & 75 & 125 & 38 & 10 & 0.4 & 28 & 2.3 & 28.7 & 0.33 & 0.13 & 0.28 & 38 & 0.16 & 20 & 0.72 \\
\hline 11 & 17 & 69 & 19 & 8 & 0.32 & 6 & 1.8 & 6.51 & 0.26 & 0.02 & 0.31 & 41 & 0.3 & 35 & 0.78 \\
\hline 12 & 14 & 64 & 48 & 26 & 0.16 & 22 & 3.6 & 9.7 & 0.09 & 0.93 & 0.18 & 52 & 0.06 & 45 & 1.72 \\
\hline 13 & 8 & 83 & 39 & 15 & 0.05 & 11 & 1.4 & 15.7 & 0.15 & 0.41 & 0.04 & 72 & 0.05 & 32 & 3.81 \\
\hline 14 & 10 & 41 & 42 & 18 & 0.03 & 20 & 2.7 & 10.3 & 0.07 & 0.2 & 0.22 & 34 & 0.14 & 30 & 3.56 \\
\hline 15 & 8 & 63 & 33 & 10 & 0.26 & 16 & 16 & 5.1 & 0.65 & 0.04 & 0.14 & 21 & 0.19 & 60 & 2.97 \\
\hline 16 & 7 & 120 & 75 & 6 & 0.33 & 27 & 32 & 16.3 & 0.28 & 0.09 & 0.24 & 15 & 0.21 & 80 & 4.67 \\
\hline 17 & 13 & 126 & 50 & 22 & 0.48 & 31 & 4.3 & 9.14 & 0.34 & 0.06 & 0.27 & 28 & 0.28 & 40 & 5.72 \\
\hline 18 & 20 & 148 & 29 & 8 & 0.21 & 23 & 12 & 25.31 & 0.5 & 0.28 & 0.2 & 36 & 0.02 & 50 & 0.35 \\
\hline 19 & 15 & 134 & 22 & 5 & 0.39 & 18 & 2.8 & 6.1 & 0.77 & 0.31 & 0.3 & 44 & 0.03 & 20 & 1.13 \\
\hline 20 & 22 & 365 & 51 & 16 & 0.17 & 13 & 5.1 & 12.7 & 0.82 & 0.05 & 0.26 & 56 & 0.12 & 30 & 0.61 \\
\hline
\end{tabular}

\section{CONCLUSION}

Water quality evaluation in the study area indicated that the $\mathrm{pH}$, total dissolved solid (TDS), conductivity and the concentrations of $\mathrm{Mg}^{2+}, \mathrm{Na}^{+}, \mathrm{Cu}^{2+}, \mathrm{Ca}^{2+}, \mathrm{Zn}^{2+}, \mathrm{Fe}^{2+}, \mathrm{NO}_{3}^{-}$, $\mathrm{SO}_{4}{ }^{2-}$, and $\mathrm{Cl}^{-}$are within WHO (1996) standards for potable water. The Piper diagram indicated that the water is of $\mathrm{Ca}-\mathrm{HCO}_{3}$ type. Continuous monitoring of the ground water quality is necessary both from the Federal and State governments, private organizations and individuals because the quality of groundwater changes especially where there is continuous development. In addition, people should be encouraged to adopt simple water treatment practices before they make use of the water.

\section{REFERENCES}

Ajibade, A. C., Fitches W. R. \& Wright J. B., (1987). The Basement Complex of Nigeria: Recognition of major tectonic unit. Rev de Geol. Physical, 21(5): 55 - 79.

Amadi, A.N., Olasehinde P.I., Okosun, E.A. and Yisa J. (2010). Assessment of the water quality index of Otamiri and Oramiriukwa Rivers. Physics International, 1(2): 116-123.

Anornu, G. K., Kortatsi, B. K., and Saeed, Z. M. (2009). Evaluation of Groundwater Resources Potential in the EjisuJuaben Disrict of Ghana. African Journal of Environmental Science and Technology, 3(10): 332-340.

Berhanu, G. (1996). The origin of high bicarbonate and fluoride concentrations in water of the main Ethiopian Rift valley, East African Rift System. Journal of African Earth Sciences, 22(4): 391-402.
Bear, J., Cheng, A. H. D., Sorek, S.,Quazar, D. and Herrera, I. (2000). Seawater intrusion in coastal Aquifer Concept, Methods and Practices. Journal of Hydrology, 118: $1-18$.

Buchanan T. J. (1983). Artificial research of ground water, international Water Technology Conference and Exposition (AUGA EXPO 83) Acapulco, Mexico.8-24.

Chapman, D. (1996). Water Quality Assessment: A guide to use of biota. Published by E \& FN Spon, 2-6 Boundary Row, London, SEI 8HN.

Eludoyin, A. O., Ofoezie, I. E. and Ogunkoya O. O. (2004). The effects of Oja-titun market effluent on the chemical quality of receiving Opa reservoir in Ile-Ife, Nigeria. Journal of Environmental Management, 72: 249-259.

Ige, O. O, Bale R. B., \& Olasehinde, P. I. (2008). Physico-Chemical characteristics of water sources in Imeko, Southwestern Nigeria. Water Resources 18: 32-36.

Nigerian Geological Survey Agency: Geological Map of Abuja. Federal Ministry of Mines and Power.

Olasehinde, P. I. (1998): Groundwater Potentials of Kwara State, Paper presented at the NMGS workshop, Kwara State Chapter, 1- 4.

Oyawoye, M. O. (1964). Geology of Nigerian Basement Complex. Journal of Mining and Geology, 4(1): 110-121.

Piper, A. M. (1944). A Graphical Procedure in the Geochemical interpretation of Water Analysis. Transaction American Geophysical Union, 25: 914 - 928.

Tyson, A. N. (1993). Georgia's Groundwater Resource. U.S. Geological Survey. Bulletin paper 1096: 1-11.

Usman, O. A. S. and Dosumu O. O. (2006). Cadmium analysis in fertilizers and groundwater samples in Dass local 
government area of Bauchi State, Nigeria. Centre point (Science Edition). 18(1\& 2): 208-213.
WHO (1996). Guideline for Drinking Water Quality. $2^{\text {nd }}$ edition, 130. 